\title{
Innately water soluble isatoic anhydrides with modulated reactivities for RNA SHAPE analysis
}

Adam B. Fessler, ${ }^{1,3, \$}$ Abhishek Dey, ${ }^{2,} \$$ Dominic S. Finis, ${ }^{1}$ Anthony J. Fowler, ${ }^{4}$ Kausik Chakrabarti, ${ }^{2}$ Craig A. Ogle $e^{1,3, *}$

${ }^{1}$ Department of Chemistry, ${ }^{2}$ Department of Biological Sciences, ${ }^{3}$ The Center for Biomedical Engineering and Science, University of North Carolina at Charlotte, Charlotte, NC 28223. ${ }^{4}$ NuChemie, LLC, Charlotte, NC 28227.

*cogle@uncc.edu

Table of Contents

Determination of $1 \mathrm{M} 7$ water solubility

Synthesis and characterization of $\mathbf{3 a}$

Synthesis and characterization of $\mathbf{4 a}$

Synthesis and characterization of $\mathbf{3} \mathbf{b}$

Synthesis and characterization of $\mathbf{4 b}$

Synthesis and characterization of $\mathbf{5}$

Synthesis and characterization of $\mathbf{6}$

Figure S6: ${ }^{1} \mathrm{H}$ NMR of 6

Methods of SHAPE of PfU3snoRNA

Methods of RNA SHAPE of TbTR

Signal to background calculation

High Resolution Mass Spectrometry 


\section{Determination of 1M7 water solubility.}

A $2 \mathrm{mM}$ standard solution of 1,4-dioxane in $\mathrm{D}_{2} \mathrm{O}$ was prepared by dilution of $0.17 \mu \mathrm{L}$ 1,4-dioxane to $1.0 \mathrm{~mL}$ final volume with $\mathrm{D}_{2} \mathrm{O}$. This solution was equilibrated to $25{ }^{\circ} \mathrm{C}$. $1 \mathrm{~mL}$ was added to an Eppendorf tube containing $15 \mathrm{mg} 1 \mathrm{M} 7$. The tube was vortexed vigorously for $30 \mathrm{~s}$ and the resulting suspension was filtered through a $0.2 \mu \mathrm{M}$ syringe filter into an NMR tube and run on a $500 \mathrm{MHz}$ JOEL EC500 NMR for 16 scans with 20 s relaxation. The integration values of 1M7 was set by the $\mathrm{N}$-methyl group of the isatoic anhydride at $3.77 \mathrm{ppm}$. 1,4-dioxane peak at $3.64 \mathrm{ppm}$ $(8 \mathrm{H})$ integrated $\sim 22.5$ times high. The concentration of $1 \mathrm{M} 7$ was therefore determined to be $\approx 0.1$ $\mathrm{mM}$.

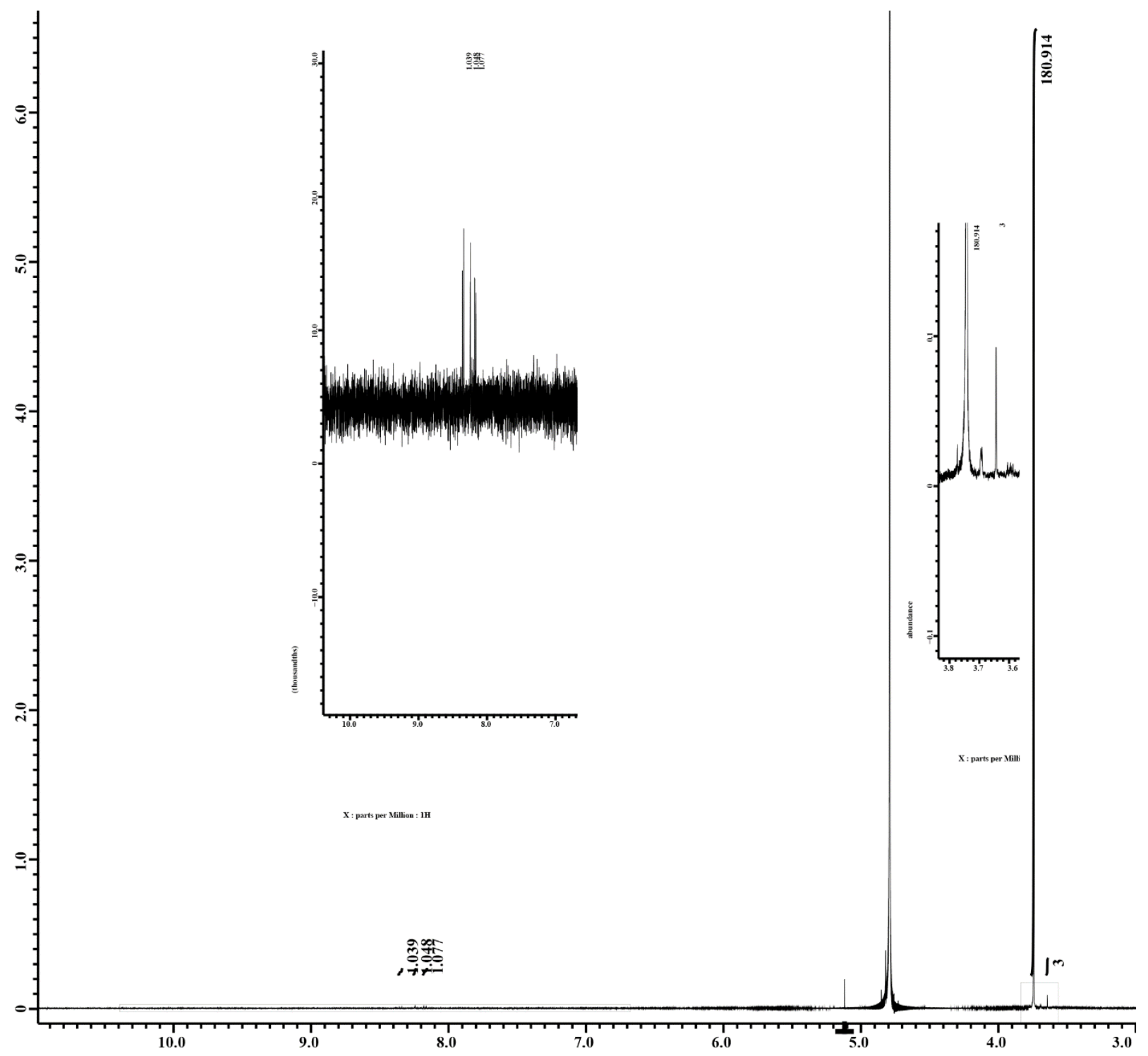

Figure S1: NMR determination of $1 \mathrm{M} 7$ water solubility $25^{\circ} \mathrm{C}$ in $\mathrm{D}_{2} \mathrm{O}$, picture in picture images shown to demonstrate clean $1 \mathrm{M} 7$ and relative integrations of aromatic protons. 


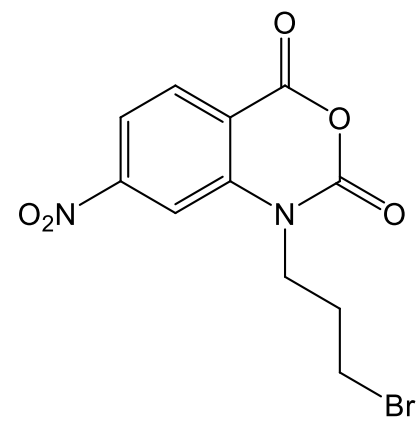

3a. A dry Schlenk flask equipped with a stir bar and flushed with $\mathrm{N}_{2}$ was charged with $\mathrm{NaH}$ $(0.06 \mathrm{~g}, 2.3 \mathrm{mmol})$ and to this, dry DMF was added $(10 \mathrm{~mL}) .6$-nitroisatoic anhydride $(300 \mathrm{mg}$, $1.4 \mathrm{mmol}$ ) was added to the solution slowly and then subsequently rinsed down the glass with dry DMF. To the reaction mixture, 1-bromo-3-chloropropane (1.0 eq, $1.4 \mathrm{mmol}$ ) was added in one portion. The reaction stirred at RT overnight. The solution was then concentrated under reduced pressure, the crude residue was dissolved with DCM and washed 6x with ice cold DI $\mathrm{H}_{2} \mathrm{O}$. The organic layer was dried overnight with $\mathrm{Na}_{2} \mathrm{SO}_{4}$, filtered, and concentrated under reduced pressure to afford a bright orange powder. $(160 \mathrm{mg}, 34 \%) \mathrm{C}_{11} \mathrm{H}_{9} \mathrm{BrN}_{2} \mathrm{O}_{5}(329.11),{ }^{1} \mathrm{H}$ NMR (300 MHz, DMSO-d6): $\delta 8.30(\mathrm{~d}, 1 \mathrm{H}), 8.21(\mathrm{t}, 1 \mathrm{H}), 8.09(\mathrm{~d}, 1 \mathrm{H}), 4.23(\mathrm{t}, 2 \mathrm{H}), 3.83(\mathrm{t}, 2 \mathrm{H})$, $2.1(\mathrm{t}, 2 \mathrm{H}) \mathrm{ppm} .{ }^{13} \mathrm{C}$ NMR $\left(300 \mathrm{MHz}, \mathrm{DMSO}-\mathrm{d}_{6}\right): \delta 157.9,152.5,147.3,141.7,131.3,117.6$, 117.1, 109.6, 41.5, 41.3, 26.5 ppm. MS (EI): Calc.: 327.97 (M); Found: 328.0 (M) m/z.

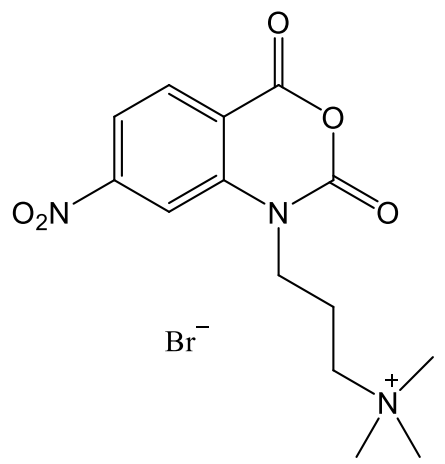

4a. To a $1.5 \mathrm{~mL}$ vial flushed with $\mathrm{N}_{2}$ was added 3a $(20 \mathrm{mg}, 61 \mu \mathrm{mol})$ in $250 \mu \mathrm{L}$ dry DMF. To this was added 2.5 eq $2 \mathrm{M}$ trimethylamine in THF $(54 \mu \mathrm{L}, 0.152 \mathrm{mmol})$. The vial is sealed and placed at RT overnight. Ethyl ether was added to triturate product from DMF. Vial is washed 5x with ethyl ether, then the residual solvent is removed under reduced pressure. Product was isolated as bright yellow solid. (2 mg, 8\%). $\mathrm{C}_{14} \mathrm{H}_{18} \mathrm{BrN}_{3} \mathrm{O}_{5}$ (387.04), ${ }^{1} \mathrm{H}$ NMR (500 MHz, DMSO-d6): $\delta 8.30$ $(\mathrm{d}, 1 \mathrm{H}), 8.16(\mathrm{~s}, 1 \mathrm{H}), 8.09(\mathrm{~d}, 1 \mathrm{H}), 4.24(\mathrm{t}, 2 \mathrm{H}), 3.40(\mathrm{~m}, 2 \mathrm{H}), 3.06(\mathrm{~s}, 9 \mathrm{H}) 2.14(\mathrm{t}, 2 \mathrm{H}) \mathrm{ppm} .{ }^{13} \mathrm{C}$ NMR (500 MHz, DMSO-d6): $\delta$ 157.9, 152.8, 147.5, 141.9, 131.6, 117.9, 116.9, 109.8, 62.6, 52.3, 41.8, 20.5 ppm. HRMS (ESI): Calc: $308.1246\left(\mathrm{M}^{+}\right)$; Found: $308.1226\left(\mathrm{M}^{+}\right) \mathrm{m} / \mathrm{z}$. 


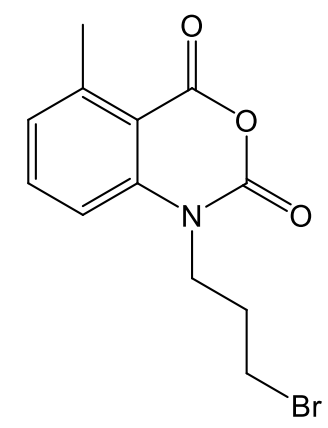

$\underline{\text { 3b. }}$. A dry Schlenk flask equipped with a stir bar and flushed with $\mathrm{N}_{2}$ was charged with $\mathrm{NaH}(0.06$ $\mathrm{g}, 2.3 \mathrm{mmol})$ and to this, dry DMF was added $(10 \mathrm{~mL})$. 6-methylisatoic anhydride (300 mg, 1.7 $\mathrm{mmol}$ ) was added to the solution slowly and then subsequently rinsed down the glass with dry DMF $(10 \mathrm{~mL})$. To the reaction mixture, 1-bromo-3-chloropropane $(1.0 \mathrm{eq}, 1.7 \mathrm{mmol})$ was added in one portion. The reaction stirred at RT overnight. The solution was then concentrated under reduced pressure, the crude residue was dissolved with DCM and washed 6x with ice cold DI $\mathrm{H}_{2} \mathrm{O}$. The organic layer was dried overnight with $\mathrm{Na}_{2} \mathrm{SO}_{4}$, filtered, and concentrated under reduced pressure. Product was isolated as a light brown solid $(1.1 \mathrm{~g}, 51 \%) . \mathrm{C}_{12} \mathrm{H}_{12} \mathrm{BrNO}_{3}(298.14),{ }^{1} \mathrm{H}$ NMR (500 MHz, DMSO): $\delta 7.69(\mathrm{t}, 1 \mathrm{H}), 7.35(\mathrm{~d}, 1 \mathrm{H}), 7.18(\mathrm{~d}, 1 \mathrm{H}), 4.06(\mathrm{t}, 2 \mathrm{H}), 3.37(\mathrm{t}, 2 \mathrm{H}), 2.64$ (s, 3H), 2.15 (p, 1H). ${ }^{13} \mathrm{C}$ NMR (300 MHz, DMSO): $\delta 157.9,141.8,143.2,142.4,135.9,126.4$, 112.5, 110.4, 42.2, 30.5, 22.3, 3.73 ppm. MS (EI): Calc. 297.0; Found: 297.1 (M) m/z

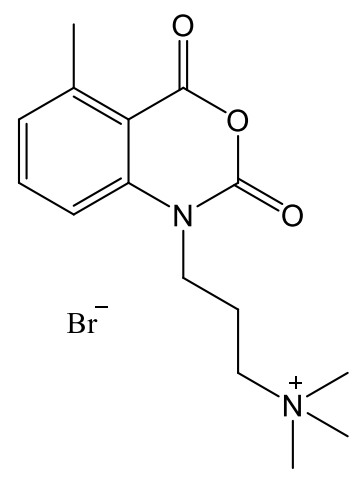

$\underline{4 \mathbf{b}}$. To a $1.5 \mathrm{~mL}$ vial flushed with $\mathrm{N}_{2}$ was added $\mathbf{3 b}(168 \mathrm{mg}, 56 \mu \mathrm{mol})$ in $1000 \mu \mathrm{L}$ dry acetone. To this was added roughly 2.5 eq $2 \mathrm{M}$ trimethylamine in THF $(54 \mu \mathrm{L}, 0.152 \mathrm{mmol})$. The vial is sealed and placed at RT overnight. Vial is washed $5 \mathrm{x}$ with ethyl ether then the residual solvent is removed under reduced pressure Final product isolated as a light brown powder (119 mg, 59\%). $\mathrm{C}_{15} \mathrm{H}_{21} \mathrm{BrN}_{2} \mathrm{O}_{3}(356.07),{ }^{1} \mathrm{H}$ NMR (500 MHz, DMSO): $\delta 7.72(\mathrm{t}, 1 \mathrm{H}), 7.42(\mathrm{~d}, 1 \mathrm{H}), 7.22(\mathrm{~d}, 1 \mathrm{H})$, $4.11(\mathrm{t}, 2 \mathrm{H}), 3.49(\mathrm{~m}, 2 \mathrm{H}), 3.04(\mathrm{~s}, 9 \mathrm{H}), 2.66(\mathrm{~s}, 3 \mathrm{H}), 2.09(\mathrm{~m}, 9 \mathrm{H}) \mathrm{ppm} .{ }^{13} \mathrm{C}$ NMR $(500 \mathrm{MHz}$, DMSO): $\delta$ 157.9, 147.9, 143.4, 142.2, 136.1, 126.6, 112.7, 110.31, 62.6, 52.2, 41.7, 22.3, 20.6, ppm. HRMS (ESI): Calc: $277.1552\left(\mathrm{M}^{+}\right)$; Found: $277.1544\left(\mathrm{M}^{+}\right) \mathrm{m} / \mathrm{z}$ 


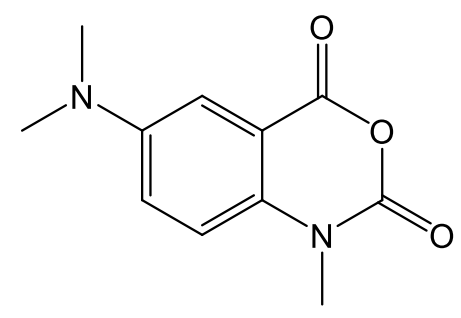

5. A dry Schlenk flask equipped with a stir bar, flushed with $\mathrm{N}_{2}$, was charged with $\mathrm{NaH}(0.06 \mathrm{~g}$, $2.3 \mathrm{mmol}$ ) and to this, dry DMF was added $(10 \mathrm{~mL}) .5$-dimethylaminoisatoic anhydride ( $300 \mathrm{mg}$, $1.5 \mathrm{mmol}$ ) was added to the solution slowly and then subsequently rinsed down the glass with dry DMF (2-3 mL). To the reaction mixture, $\mathrm{CH}_{3} \mathrm{I}(1.0 \mathrm{eq}, 1.5 \mathrm{mmol})$ was added in one portion. The reaction stirred at RT overnight. The solution was then concentrated under reduced pressure, the crude residue was dissolved with DCM and washed 6x with an ice cold solution of saturated sodium bicarbonate. The organic layer was dried with $\mathrm{Na}_{2} \mathrm{SO}_{4}$, filtered, and concentrated under reduced pressure to afford a faint green solid. (207 mg, 65\%). $\mathrm{C}_{11} \mathrm{H}_{12} \mathrm{~N}_{2} \mathrm{O}_{3},{ }^{1} \mathrm{H}$ NMR $(500 \mathrm{MHz}$, DMSO-d6): $\delta 7.31(\mathrm{~d}, 2 \mathrm{H}), 7.14(\mathrm{t}, 1 \mathrm{H}), 3.42(\mathrm{~s}, 3 \mathrm{H}), 2.94(\mathrm{~s}, 6 \mathrm{H}) \mathrm{ppm} .{ }^{13} \mathrm{C}$ NMR $(500 \mathrm{MHz}$, DMSO-d6): $\delta 159.9,148.1,147.3,147.3,133.3,122.7,116.4,110.1,40.9,32.1$ ppm. HRMS (EI): Calc. 221.0926; Found: $221.0917\left(\mathrm{MH}^{+}\right) \mathrm{m} / \mathrm{z}$.

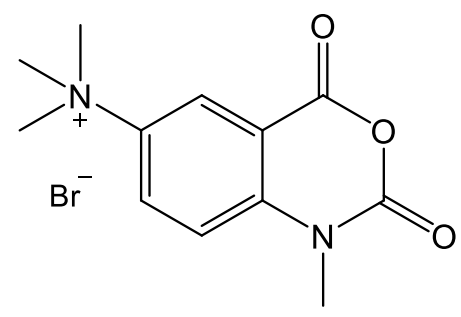

6. To a $1.5 \mathrm{~mL}$ vial flushed with $\mathrm{N}_{2}$ was added $5(100 \mathrm{mg}, 0.45 \mathrm{mmol})$ through a $0.2 \mu \mathrm{m}$ filter in $750 \mu \mathrm{L}$ dry acetone. To this was added excess $\mathrm{MeBr}$ condensed in $250 \mu \mathrm{L}$ cold acetone. The vial was sealed and placed at RT overnight. Vial was washed $5 \mathrm{x}$ with ethyl ether then the residual solvent is removed under reduced pressure. (65 mg, 50\%). $\mathrm{C}_{12} \mathrm{H}_{15} \mathrm{BrN}_{2} \mathrm{O}_{3}(315.17),{ }^{1} \mathrm{H}$ NMR (500 MHz, DMSO-d6): $\delta 8.44(\mathrm{~m}, 2 \mathrm{H}), 7.69(\mathrm{~s}, 1 \mathrm{H}), 3.66(\mathrm{~s}, 9 \mathrm{H}), 3.51(\mathrm{~s}, 3 \mathrm{H}) \mathrm{ppm} .{ }^{13} \mathrm{C}$ NMR $(500$ MHz, DMSO-d6): $\delta 158.1,147.4,142.9,141.9,129.2,121.3,116.7,112.2,56.5,32.1$ ppm. HRCMS (ESI): Calc. 235.1083; Found: $235.1071(\mathrm{M}+) \mathrm{m} / \mathrm{z}$ 


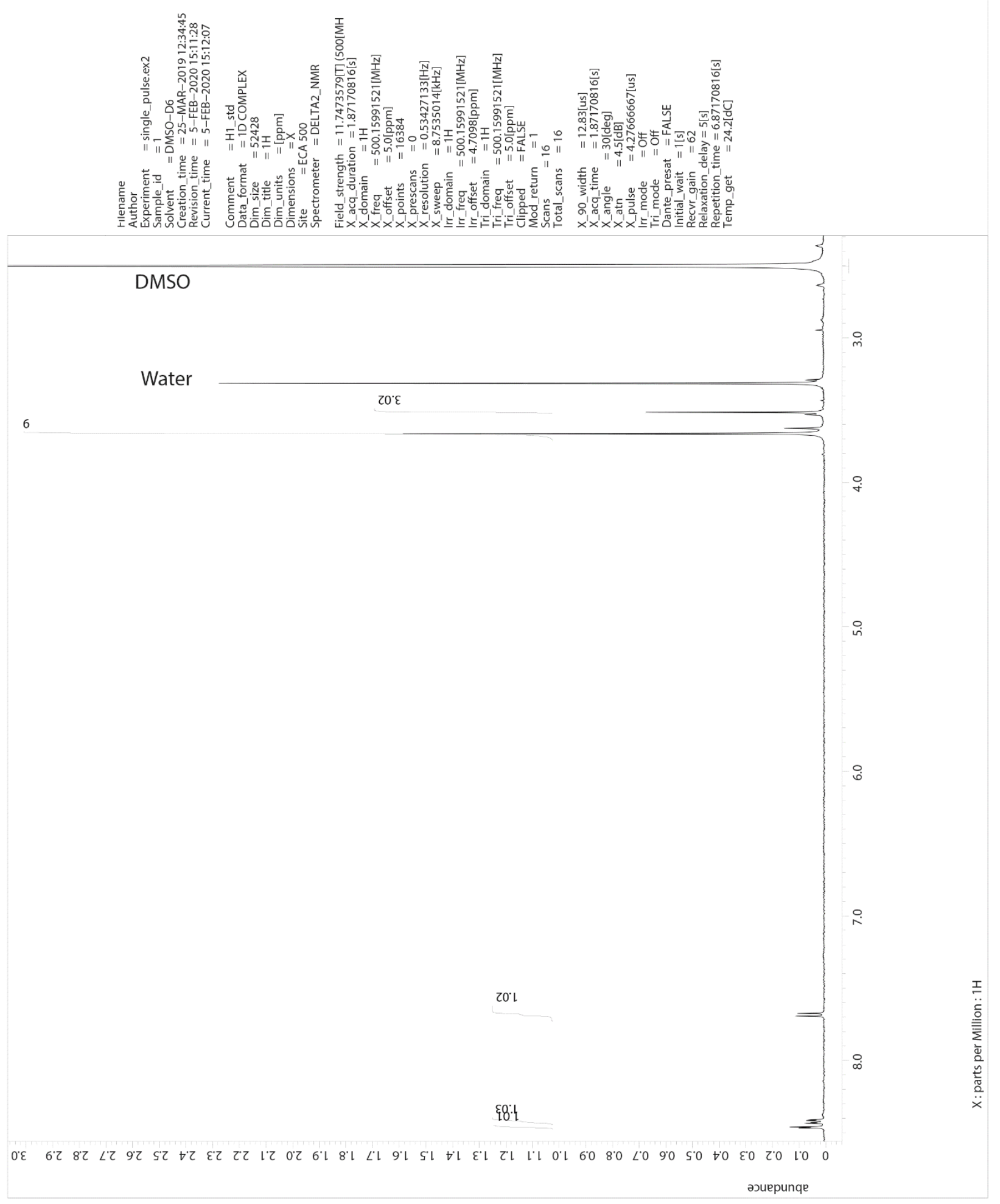

Figure S2: ${ }^{1} \mathrm{H}$ NMR of 6 


\section{PCR amplification and in vitro Transcription:}

Primary PCR amplification of Plasmodium falciparum U3 small nucleolar RNA (snoRNA) was done from genomic DNA of Plasmodium falciparum 3D7 strain as described earlier. ${ }^{1}$ The resultant PCR amplified DNA of PfU3 snoRNA was in vitro Transcribed (IVT) and purified using the MEGAscript and MEGAclear kits (Life Technologies, USA) following the manufacturer's recommendation.

\section{in vitro SHAPE modification:}

For SHAPE modification of PfU3snoRNA, $5 \mu \mathrm{g}$ of in vitro transcribed RNA was denatured by heating at $95{ }^{\circ} \mathrm{C}$ for $2 \mathrm{~min}$ followed by immediate incubation on ice for $3 \mathrm{~min}$. The modification was carried out by incubation of the RNA in $3 X$ SHAPE buffer consisting of $333 \mathrm{mM}$ of $\mathrm{NaCl}$, $333 \mathrm{mM}$ of HEPES and $20 \mathrm{mM}$ of $\mathrm{MgCl}_{2}$ at $37{ }^{\circ} \mathrm{C}$ prior to the addition of $10 \mathrm{mM}$ of $1 \mathrm{M} 7,4 \mathbf{b}$ and 6 for $70 \mathrm{sec}$. Following incubation, the modified RNA was ethanol precipitated, dissolved in water and subjected to nanodrop analysis.

\section{cDNA synthesis and RNA-SHAPE analysis by denaturing Polyacrylamide Gel Electrophoresis (PAGE):}

$1.6 \mu \mathrm{g}$ of SHAPE modified RNA was denatured by heating at $95{ }^{\circ} \mathrm{C}$ for 2 min followed by immediate incubation on ice for $3 \mathrm{~min}$. For Primer extension, $5^{\prime}$ cy 5 labelled primer (Table S1) for reverse transcription along with $10 \mathrm{mM}$ dNTPs were mixed with the SHAPE modified RNA and incubated at $65{ }^{\circ} \mathrm{C}$ for $5 \mathrm{~min}$. Four dideoxy sequencing reactions using ddNTPs were also performed in parallel using the unmodified PfU3 snoRNA in the similar manner as mentioned above. Following incubation, all the reactions were supplemented with 1X SuperScript II Firststrand buffer (50mM Tris-HCl, $\mathrm{pH} 8.3,75 \mathrm{mM} \mathrm{KCl}$ and $5 \mathrm{mM} \mathrm{MgCl} 2), 10 \mathrm{mM}$ DTT and $1 \mu \mathrm{L}$ of RiboLock RNase inhibitor and incubated at $42{ }^{\circ} \mathrm{C}$ for $2 \mathrm{~min}$. After addition of SuperScript II Reverse Transcriptase enzyme, the whole reaction was incubated at $42{ }^{\circ} \mathrm{C}$ for $60 \mathrm{~min}$, followed by inactivation at $70{ }^{\circ} \mathrm{C}$ for $15 \mathrm{~min}$. The, resultant mixtures of cDNA were precipitated by adding isopropanol and then dissolved in water. cDNA generated from primer extension were mixed with $80 \%$ formaldehyde, heated at $80{ }^{\circ} \mathrm{C}$ for 3 min and then resolved by $12 \%$ denaturing PAGE gel. The gel was scanned using Typhoon phosphorimager (Figure S2). Nucleotide position for each band was identified form dideoxy sequencing lane (Figure S2). Secondary structure of RNA was generated by Mfold $^{2}$ and the SHAPE reactivities of accessible nucleotide were mapped on it.

Table S1: Primer used for PfU3 snoRNA cDNA synthesis

\begin{tabular}{l|l} 
Name & Sequence \\
\hline PfU3 snoRNA RT & $5^{\prime}$ cy5- AAG TTC AGC GGA CGC AAG CTC-3'
\end{tabular}



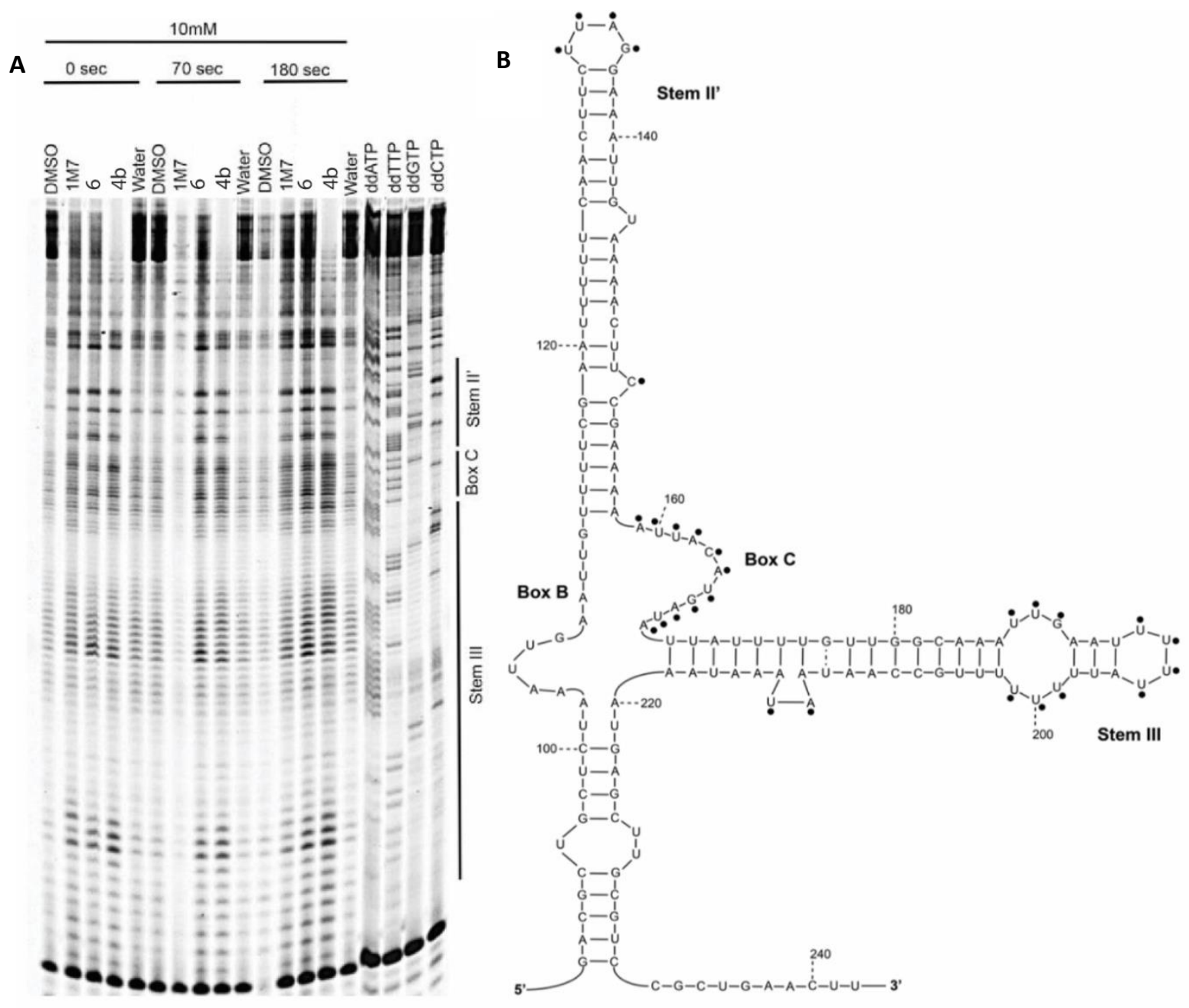

Figure S3: (A) cy5 labeled denaturing gel comparing modifications in the synthetic pfU3 snoRNA using 1M7 and $\mathbf{4 b}$ and $\mathbf{6}$ at $10 \mathrm{mM}$ concentration (B) Partial secondary structure of PfU3 snoRNA. Nucleotides modified by the SHAPE electrophiles are indicated by black circles 


\section{in vitro Transcription of TbTR catalytic core:}

The catalytic core of $T$. brucei telomerase RNA (TbTR) comprising of the Template boundary element (TBE), Template and Template proximal and distal helix regions were synthesized as a G-block oligos from IDT. T7 RNA promoter sequence was added to the 5' end of TBE during the synthesis. The resultant oligos was in vitro transcribed (IVT) using the MEGAscript and purified MEGAclear kit (Life Technologies, USA) following the manufacturer's recommendation. The resultant RNA was quantified by nanodrop analysis.

\section{in vitro SHAPE modification:}

For SHAPE modification of TbTER catalytic core, $5 \mu \mathrm{g}$ of in vitro transcribed RNA was denatured by heating at $95{ }^{\circ} \mathrm{C}$ for $2 \mathrm{~min}$ followed by immediate incubation on ice for $3 \mathrm{~min}$. The modification was carried out by incubating the RNA in 3X SHAPE buffer consisting of $333 \mathrm{mM}$ of NaCl, 333 $\mathrm{mM}$ of HEPES and $20 \mathrm{mM}$ of $\mathrm{MgCl}_{2}$ at $37{ }^{\circ} \mathrm{C}$ prior to the addition of $10 \mathrm{mM}$ of $1 \mathrm{M} 7, \mathbf{6}$ and $\mathbf{4 b}$ for $70 \mathrm{sec}$. As a negative control equivalent amount of DMSO/water was added to the RNA. Following incubation, the modified RNA was ethanol precipitated, dissolved in water and subjected to nanodrop analysis prior to cDNA synthesis.

\section{cDNA synthesis and RNA-SHAPE analysis by denaturing Polyacrylamide Gel Electrophoresis (PAGE):}

$1.6 \mu \mathrm{g}$ of SHAPE modified RNA was denatured by heating at $95{ }^{\circ} \mathrm{C}$ for $2 \mathrm{~min}$ followed by immediate incubation on ice for 3 min. For Primer extension, 5' cy5 labelled primer (Table S2) for reverse transcription along with $10 \mathrm{mM}$ dNTPs were mixed with the SHAPE modified RNA and incubated at $65{ }^{\circ} \mathrm{C}$ for $5 \mathrm{~min}$. Four dideoxy (dd) sequencing reactions were also performed using the unmodified TbTR catalytic core in the similar manner as mentioned above. Additionally, to the individual sequencing reactions were also added ddATP, ddTTP, ddGTP and ddCTP. Following incubation all the reactions were supplemented with 1X SuperScript II First-strand buffer (50 mM Tris-HCl, pH 8.3, $75 \mathrm{mM} \mathrm{KCl}$ and $5 \mathrm{mM} \mathrm{MgCl2}$ ), $10 \mathrm{mM}$ DTT and $1 \mu \mathrm{l}$ of RiboLock RNase inhibitor and incubated at $42{ }^{\circ} \mathrm{C}$ for $2 \mathrm{~min}$. After addition of SuperScript II Reverse Transcriptase enzyme, the whole reaction was incubated at $42{ }^{\circ} \mathrm{C}$ for $60 \mathrm{~min}$, followed by inactivation at $70{ }^{\circ} \mathrm{C}$ for $15 \mathrm{~min}$. The, resultant mixtures of cDNA were precipitated by adding isopropanol and then dissolved in water. cDNA generated from primer extension were mixed with $80 \%$ formaldehyde, heated at $80{ }^{\circ} \mathrm{C}$ for $3 \mathrm{~min}$ and then resolved by $12 \%$ denaturing PAGE gel. The gel was scanned using Typhoon phosphorimager. Nucleotide position for each band was identified form dideoxy sequencing lane. Secondary structure of TbTR catalytic core was generated by RNAstructure software ${ }^{3}$ and the SHAPE reactivities of accessible nucleotide were mapped on it.

Table S2: Primer used for TbTR Catalytic core cDNA synthesis

\begin{tabular}{|c|c|}
\hline Name & Sequence \\
\hline TbTR-Template RT & $5^{\prime}$ cy5- TAT TGC ACA CCA ACA GCA CTA -3' \\
\hline TbTR-Template Proximal helix RT & $5^{\prime}$ cy5- CAA TGA TGA CGT GAA GAG GAG GA -3' \\
\hline TbTR-Template Distal helix RT & 5' cy5- TAA ACA AAC CGG CTA GAG AGG -3' \\
\hline
\end{tabular}




\section{Signal-to-background ratio calculation:}

Signal-to-background ratio (S/B) is the arithmetic mean of intensity of bands for sample lanes (except the dideoxy sequencing reactions and control lanes) to the background. Mean Pixel intensity of randomly chosen three bands for sample lane was calculated using ImageJ software and divided by the mean pixel intensity of background which is the low intensity region present adjacent to each band. Same position bands were used for calculation for each lane.

\section{High Resolution Mass Spectrometry:}

High resolution MS data were analyzed on an Orbitrap XL in positive mode at a resolution of 60000 , spray voltage of $5 \mathrm{kV}$, sheath 12, Aux 10, Sweep 0, Capillary Temp $275{ }^{\circ} \mathrm{C}$, Capillary Voltage $32.00 \mathrm{~V}$, Tube Lens of $85.00 \mathrm{~V}$ Compounds were dissolved in $1 \mathrm{~mL}$ ACN, then $8 \mu \mathrm{L}$ was diluted in $1: 1 \mathrm{H}_{2} \mathrm{O}: \mathrm{ACN}$ with $0.1 \%$ Formic acid. $2 \mu \mathrm{L}$ of this solution was injected using an Accela $1250 \mathrm{LC}$ system, at a solvent flowrate of $200 \mu \mathrm{L} / \mathrm{min}$ of $1: 1 \mathrm{H}_{2} \mathrm{O}: \mathrm{ACN}$ with $0.1 \%$ Formic Acid. X-ray data were collected on an Agilent/Oxford Diffraction Gemini A Ultra diffractometer utilizing Mo radiation $(\lambda=0.71073 \AA)$ at $100 \mathrm{~K}$.

\section{References:}

1. Fessler, A. B., Dey, A., Garmon, C. B., Finis, D. S., Saleh, N.-A., Fowler, A. J., Jones, D. S., Chakrabarti, K., and Ogle, C. A. (2018) Water-Soluble Isatoic Anhydrides: A Platform for RNASHAPE Analysis and Protein Bioconjugation. Bioconjugate Chem. 29, 3196-3202.

2. Zuker, M., (2003) Mfold web server for nucleic acid folding and hybridization prediction. Nucleic Acids Res. 31 (13), 3406.

3. Reuter, J. S.; Mathews, D. H., RNAstructure: software for RNA secondary structure prediction and analysis. BMC Bioinform. 2010, 11 (1), 129. 